\title{
Evaluation of Yield, Marketability, and Nitrate Levels of Lettuce Cultivars Produced in Southern Louisiana
}

\author{
William D. Afton ${ }^{1}$, Kathryn K. Fontenot ${ }^{1}$, Jeff S. Kuehny ${ }^{1}$, \\ and Carl E. Motsenbocker ${ }^{1}$
}

\begin{abstract}
ADDITIONAL INDEX WORDS. diet, human health, Lactuca sativa, variety
SUMMARY. Forty-five cultivars of lettuce (Lactuca sativa) were field-grown using best management practices at the Louisiana State University Agricultural Center (LSU AgCenter) Botanic Gardens in Baton Rouge during the Fall 2011 and Fall 2012 seasons. Recommended cultivars were selected for commercial production in Louisiana based on fresh weight and lettuce size (width and height). Nitrate $\left(\mathrm{NO}_{3}{ }^{-}\right)$ concentration was analyzed for each cultivar, as lettuces are known to accumulate and concentrate $\mathrm{NO}_{3}^{-}$, and were then compared with the U.S. Environmental Protection Agency's (EPA) oral reference dose (RfD-the EPA's maximum acceptable oral dose of a toxic substance) of $1.6 \mathrm{mg} \mathrm{NO}_{3}$-nitrogen $(\mathrm{N})$ per kilogram body weight per day. Recommended butterhead cultivars were Caliente and Harmony (21.6 and 13.9 pm $\mathrm{NO}_{3}{ }^{-}$, respectively); recommended green-leaf cultivars were Salad Bowl and Tango (10.6 and $4.6 \mathrm{ppm} \mathrm{NO}_{3}{ }^{-}$, respectively); recommended red-leaf cultivars were Red Salad Bowl, Red Sails, and New Red Fire (15.2, 15.4, and $24.0 \mathrm{ppm} \mathrm{NO}_{3}{ }^{-}$, respectively). The only recommended romaine cultivar was Green Towers (11.2 ppm $\left.\mathrm{NO}_{3}^{-}\right)$, and recommended crisphead cultivars included Raider and Ithaca (17.6 and $14.9 \mathrm{ppm} \mathrm{NO}_{3}{ }^{-}$, respectively). Of the highest yielding cultivars, New Red Fire accumulated the greatest $\mathrm{NO}_{3}{ }^{-}$concentration: $24.0 \mathrm{ppm}$ in both years 1 and 2 . The $\mathrm{NO}_{3}{ }^{-}$concentration is less than the levels of concern for both men and women 20 to 74 years old, $3.9 \%$ of the $\mathrm{RfD}$ for men and $4.59 \%$ of the RfD for women.
\end{abstract}

$\mathrm{L}$ ettuce (Lactuca sativa) is a commonly consumed vegetable crop in current food systems. In 2009, the per-capita consumption of lettuce was estimated to be $28 \mathrm{lb}$ annually [U.S. Department of Agriculture (USDA), 201la]. Lettuce is consumed fresh in the form of salads or as an accompaniment for hamburgers, sandwiches, and tacos. When consumed fresh, it is an excellent source of bulk and fiber (Swiader and Ware, 2002). In the United States, romaine lettuce and leaf lettuce production have increased $192 \%$, from 58,700 acres planted in 1992 to 171,400 acres planted in 2018 (Sen Nag, 2017; USDA, 2011b, $2011 \mathrm{lc}$ ). Crisphead lettuce production decreased

Received for publication 30 Apr. 2020. Accepted for publication 21 Aug. 2020.

Published online 18 September 2020.

${ }^{1}$ School of Plant, Environmental and Soil Science, Louisiana State University, 104 Sturgis Hall, Baton Rouge, LA 70803

W.D.A. is the corresponding author. E-mail: wafton@ agcenter.lsu.edu.

This is an open access article distributed under the CC BY-NC-ND license (https://creativecommons.org/ licenses/by-nc-nd/4.0/).

https://doi.org/10.21273/HORTTECH04642-20 in total acreage by $20 \%$ from 216,840 acres planted in 1992 to 120,700 acres planted in 2018 (USDA, $2011 \mathrm{~d}$ ). Lettuce is one of the leading fresh-market vegetables in acreage, production, and gross farm value. California and Arizona are the leading producers in the United States, harvesting 213,900 and 75,300 acres, respectively (Sen Nag, 2017). China leads the world production, harvesting 13.5 million tonnes in 2013, followed by the United States and
Spain, harvesting 3.6 and 1.1 million tonnes, respectively (Sen Nag, 2017).

Lettuce is classified into four groups: crisphead, butterhead, romaine, and loose leaf. Crisphead lettuce is also referred to as iceberg lettuce. Swiader and Ware (2002) define each of these categories of lettuce by physical characteristics. Crisphead is described as having a large, solid head weighing more than $1.99 \mathrm{lb}$ and measuring more than 5.9 inches in diameter. The leaves are crisp and brittle, with prominent veins and midribs. Crisphead is more tolerant of shipping and handling than all other types and therefore is the leading type of lettuce grown in the United States (USDA, 2011d). The Swiader and Ware (2002) characterization of romaine lettuce is long, narrow foliage; upright growth habit; and loose, elongated heads whereas butterhead lettuce is characterized by smooth, soft, and pliable leaves forming a loose head. The veins and midribs of butterhead types are not as prominent as in crisphead types and are considered to have better table quality and a more delicate flavor than crisphead types. Swiader and Ware (2002) subcategorize butterhead lettuce into two groups: Boston and bibb lettuce. Bibb lettuce is smaller and darker green than Boston lettuce. Loose-leaf lettuce is characterized as producing an open rosette of leaves arranged loosely on the stalk. There is a considerable amount of variation in leaf color within loose-leaf lettuce, ranging from green and purple to red. There is also variation in loose-leaf texture and margin shape (Swiader and Ware, 2002).

\begin{tabular}{clll}
\hline $\begin{array}{l}\text { Units } \\
\text { To convert U.S. to SI, } \\
\text { multiply by }\end{array}$ & U.S. unit & SI unit & $\begin{array}{l}\text { To convert SI to U.S., } \\
\text { multiply by }\end{array}$ \\
\hline 0.4047 & acre $(\mathrm{s})$ & $\mathrm{ha}$ & 2.4711 \\
29.5735 & $\mathrm{fl} \mathrm{oz}$ & $\mathrm{mL}$ & 0.0338 \\
0.3048 & $\mathrm{ft}$ & $\mathrm{m}$ & 3.2808 \\
2.54 & inch $(\mathrm{es})$ & $\mathrm{cm}$ & 0.3937 \\
25.4 & inch $(\mathrm{es})$ & $\mathrm{mm}$ & 0.0394 \\
0.4536 & $\mathrm{lb}$ & $\mathrm{kg}$ & 2.2046 \\
1.1209 & $\mathrm{~b} / \mathrm{acre}$ & $\mathrm{kg} \cdot \mathrm{ha}^{-1}$ & 0.8922 \\
28.3495 & $\mathrm{oz}$ & $\mathrm{g}$ & 0.0353 \\
28,350 & $\mathrm{oz}$ & $\mathrm{mg}$ & $3.5274 \times 10^{-5}$ \\
1 & $\mathrm{ppm}$ & $\mathrm{mg} \cdot \mathrm{kg}^{-1}$ & 1 \\
1.1692 & $\mathrm{pt} / \mathrm{acre}$ & $\mathrm{L} \cdot \mathrm{h}{ }^{-1}$ & 0.8553 \\
0.9464 & $\mathrm{qt}$ & $\mathrm{L}$ & 1.0567 \\
0.9072 & ton $(\mathrm{s})$ & tonne $(\mathrm{s})$ & 1.1023 \\
$\left({ }^{\circ} \mathrm{F}-32\right) \div 1.8$ & ${ }^{\circ} \mathrm{F}$ & ${ }^{\circ} \mathrm{C}$ & $\left({ }^{\circ} \mathrm{C} \times 1.8\right)+32$
\end{tabular}


Although lettuces vary in physical differences, all subcategories assimilate and concentrate $\mathrm{NO}_{3}{ }^{-}$in their leaf tissue. $\mathrm{NO}_{3}{ }^{-}$is incorporated into proteins and other nitrogenous compounds and is used as a terminal electron receptor in the respiratory chain of chloroplasts (Hill, 1996). $\mathrm{NO}_{3}{ }^{-}$ingestion is a human health concern. Ingestion of $\mathrm{NO}_{3}{ }^{-}$is linked to the formation of $\mathrm{N}$-nitroso compounds, most of which are labeled carcinogens and teratogens. Ingestion is also linked to methemoglobinemia (blue baby syndrome) and adverse pregnancy outcomes (Ward et al., 2018).

Therefore, the objectives of this study were to determine the optimum yielding lettuce cultivars for Louisiana commercial production and to determine whether the greatest yielding cultivars accumulated $\mathrm{NO}_{3}{ }^{-}$at levels that could potentially pose a threat to human health.

\section{Materials and methods}

A lettuce trial was planted at the LSU AgCenter Botanic Gardens, Baton Rouge (lat. $30^{\circ} 24^{\prime} 32.1012^{\prime \prime} \mathrm{N}$, long. $91^{\circ} 6^{\prime} 21.0132^{\prime \prime} \mathrm{W}$ ) using industry-standard cultivation practices (Boudreaux, 2009; Kemble et al., 2019). Forty-five cultivars of lettuce were planted in a randomized complete block design on a 0.69 -acre field over two consecutive growing seasons 2011 (year 1) to 2012 (year 2).

Glyphosate (Bayer, St. Louis, $\mathrm{MO})$ was applied as a burn-down, nonselective herbicide at a rate of 3 pt/acre (Boudreaux, 2009; Kemble et al., 2019). Four weeks before transplanting, a $13 \mathrm{~N}-5.7 \mathrm{P}-10.8 \mathrm{~K}$ fertilizer was applied as a preplant application at a rate of $80 \mathrm{lb} /$ acre $\mathrm{N}$. Black plastic mulch (Agriculture Solutions, Strong, $\mathrm{ME})$ and drip-tape [emitters on 12inch centers (Netafim, Fresno, CA)] were installed. Pronamide the active ingredient in Kerb (Dow AgroSciences, Indianapolis, IN) was applied for preemergent weed control in the row middles at a rate of $1.5 \mathrm{lb} /$ acre a.i. Herbicide was not applied under the plastic. Seed sources included Harris Seeds (Rochester, NY), Johnny's Selected Seeds (Fairfield, ME), Rupp Seeds (Wauseon, $\mathrm{OH}$ ), Siegers Seed Co. (Holland, MI), and Territorial Seed Co. (Cottage Grove, OR). Recommended cultivars for southeastern U.S. production (Kemble et al., 2019) influenced cultivar selection. All seeds were sown into 98-count plug trays (T.O. Plastics, Clearwater, MN) and filled with a medium containing fine sphagnum moss, peatmoss, vermiculite, dolomite, and a long-lasting wetting agent (Sunshine Mix \#3; Sun Gro Horticulture, Agawam, MA). Plants were monitored daily and watered as needed by hand. Using $20 \mathrm{~N}-8.7 \mathrm{P}-$ 16.6K water-soluble fertilizer, plants were fertilized weekly (Peters; Everris NA, Dublin, $\mathrm{OH}$ ) at a $200-\mathrm{ppm} \mathrm{N}$ rate. In year 1 , seeds were covered by the germinating mix $(0.25$ inch $)$ after sowing into 98 -count inserts. In year 2 , the additional 0.25 -inch soil layer was not applied to the top of seed trays. Fresh seed was purchased, and sterile trays and media were used each year. Greenhouse conditions were similar each year. Transplants were hardened $7 \mathrm{~d}$ before transplanting in the field. The field was planted in a randomized complete block design with five plots per cultivar (40 plants per plot). Plots were $40 \mathrm{ft}$ long. Two drills of lettuce plants were planted on 48-inch-wide rows. The plants were double-drilled, with 12 inches between drills and 12 inches between individual plants. Fivefoot alleyways were between each plot and between blocks. Planting dates were on 11 Nov. 2011 in year 1 and 29 Oct. 2012 in year 2. Cultivars were assigned randomly to plots within each of the five blocks. Drip irrigation was automated at $30 \mathrm{~min} / \mathrm{d}$ beginning at 7:00 AM. Calcium nitrate fertilizer $(15.5 \mathrm{~N}-0.0 \mathrm{P}-0.0 \mathrm{~K})$ was injected through irrigation lines at $20 \mathrm{lb} /$ acre $\mathrm{N}$ per week for 3 weeks starting at 28 $\mathrm{d}$ in year $\mathrm{l}$ and $25 \mathrm{~d}$ in year 2 . The center 10 plants of each cultivar in each plot were harvested for data collection. Before harvest, lettuce heads were measured for height (from soil line to top of lettuce leaf) and width (two measurements). The lettuce head size data are not provided here, but are included in the original thesis document (Afton, 2018). Individual heads were then cut 1.5 inches above the plastic mulch layer. Fresh weight was measured in the field, and then the individual heads were labeled and inserted into a 1 -qt clear plastic bag (Uline, Pleasant Prairie, WI). Leaf lettuce was harvested $40 \mathrm{~d}$ after planting in year 1 and $39 \mathrm{~d}$ in year 2. Bibb lettuce was harvested $63 \mathrm{~d}$ after planting in year 1 and $60 \mathrm{~d}$ after in year 2. Both romaine and crisphead types were harvested 67 $\mathrm{d}$ after planting in years 1 and 2 . Fresh weight was averaged between both year 1 and year 2 to determine heaviest yielding cultivars.

Leaf $\mathrm{NO}_{3}^{-}$content analysis was conducted in the LSU's Department of Agricultural Chemistry laboratories in Baton Rouge. Cultivars that averaged the greatest fresh weight were selected for $\mathrm{NO}_{3}{ }^{-}$analysis. After harvest, leaf tissue was dried for $168 \mathrm{~h}$ at $60^{\circ} \mathrm{C}$ in a plant tissue dryer $(1660$; VWR Scientific, Radnor, PA) to calculate dry weights and for later processing to determine $\mathrm{NO}_{3}{ }^{-}$accumulation. Five dried, random samples of each tested cultivar were ground and passed through a \#40 mesh sieve with $0.40-\mathrm{mm}$ openings. Two grams of each pulverized sample were added to a $250-\mathrm{mL}$ volumetric flask along with $50 \mathrm{~mL}$ deionized water. Flasks were placed into a hot water bath at $29.4{ }^{\circ} \mathrm{C}$ and shaken for $45 \mathrm{~min}$. An additional $200 \mathrm{~mL}$ of deionized water was added to each flask. Flasks were shaken and the solution was poured through a $11-\mathrm{cm}$ folded paper filter into $16 \times 125-\mathrm{mm}$ polystyrene test tubes. The filtrate was diluted by one fifth with deionized water. The diluted filtrate was then transferred to $4.0-\mathrm{mL}$ polystyrene sample cups (Fisherbrand; Thermo Fisher Scientific, Waltham, MA) and loaded into an automated segmented flow analyzer (SEAL AutoAnalyzer 3; Seal Analytical, Mequon, WI) to determine total $\mathrm{NO}_{3}{ }^{-}$concentration using the Kjeldahl total $\mathrm{N}$ method [U.S. Environmental Protection Agency (EPA), 1993]. Two separate years of data were collected but combined. Data were analyzed using SAS (version 9.2; SAS Institute, Cary, NC) with Tukey's test at $P \leq 0.05$. Using the average percent water of lettuce, $2 \mathrm{~g}$ of dried lettuce tissue is equivalent to $43 \mathrm{~g}$ of fresh-weight lettuce. The calculation is as follows. $2 \mathrm{~g}$ dried $\times[100 /(100-95.4)]=43 \mathrm{~g}$ fresh (Maynard and Hochmuth, 2007).

In addition to measuring growth characteristics, a representative sample of each cultivar was harvested from the field for a consumer rating survey. Cultivars were assigned a random number for display. Faculty, staff, and students were asked to name their top three choices of lettuce by visual appearance. The instruction 
were simple: "Please tell us the numbers of 3 lettuce heads that you would buy at the grocery store, assuming all lettuce was priced equally." Eighty-seven people participated in year 1 and 96 people participated in year 2 .

\section{Results}

Cultivar trial. Germination rates in year 2 were more than $80 \%$ for all cultivars, with the exceptions of Starfighter (53\%) and Grand Rapids (71\%) (Table 1). These two cultivars are not recommended for production in Louisiana based on this study. In year 1 , a peat-based germinating mix covered the seeds $(0.25 \mathrm{inch})$ in the 98 -count plug trays. In year 2 , the additional germinating mix $(0.25$ inch) was not applied to the top of seed trays. Fresh seed was purchased, and sterile trays and media were used each year. Greenhouse conditions were similar each year. The positive increase in germination percentage in year 2 is likely a result of increased light reaching germinating seeds.

Romaine lettuce had the heaviest fresh weight of all lettuce categories grown followed by crisphead and butterhead types.

Leaf lettuces were the lightest of all lettuce types produced in this study. However, fresh-weight differences were found among cultivars within lettuce categories (Table 2). Within the butterhead type, 'Caliente' and 'Harmony' were heavier than 'Drunken Woman Frizzy Headed', 'Esmeralda', 'Skyphos', and 'Summer Bibb'. However, 'Caliente' and 'Harmony' did not have heavier fresh weights than the remaining butterhead cultivars trialed (Table 1 ). No fresh-weight variation was found in the cultivars grown within the crisphead category. 'Great Lakes', 'Ithaca', and 'Raider' were heavier than all the leaf lettuce trialed cultivars (Table 1). Within leaf types, 'Oakleaf' was heavier than 'Cherokee' and 'Lolla Rosa'. 'Salad Bowl' was heavier than 'Lolla Rosa'; however, 'Oakleaf' and 'Salad Bowl' did not differ in fresh weight compared with the other leaf lettuce cultivars (Table 1 ). Within the romaine category, 'Ridgeline' was heavier than 'Cimmaron Red' and 'Flashy Trout Back'. There were no other fresh-weight differences within the romaine type lettuces (Table 1 ).
Romaine is generally the heaviest type of lettuce grown (Swiader and Ware, 2002); however, some lettuce cultivars within other types in this study were equal to romaine cultivars. 'Caliente' and 'Harmony' did not differ in fresh weight from 'Cuore', 'Green Towers', 'Ideal', 'Musena', 'Parris Island', 'Red Eye', 'Ridgeline', and 'Tall Guzmaine Elite'. 'Raider', a crisphead type, also produced equal fresh weight to 'Cuore', 'Green Towers', 'Ideal', 'Musena', 'Parris Island', 'Red Eye', 'Ridgeline', and 'Tall Guzmaine Elite' (Table 1).

Consumers rated 'Two Star', 'Tango', and 'New Red Fire' (all leaf types) as their top three choices for purchasing in year 1 . In year 2, consumers rated 'Red Salad Bowl' (leaf) and 'Sierra', and 'Harmony' (bibb) as the top three selections for purchasing. No one cultivar was rated as a top choice in both years.

$\mathrm{NO}_{3}{ }^{-}$EXPERIMENT. The romaine lettuce types accumulated the least amount of $\mathrm{NO}_{3}-\mathrm{N}$ (Table 2). Within butterhead and crisphead types, there were no differences in $\mathrm{NO}_{3}-\mathrm{N}$ accumulation. Within leaf lettuce, 'Cherokee' (21.9 ppm) and 'New Red Fire' $(24.0 \mathrm{ppm})$ had a greater $\mathrm{NO}_{3}-\mathrm{N}$ concentration than 'Salad Bowl' (10.6 ppm). The other two redlettuce cultivars Red Sails (15.4 ppm) and Red Salad Bowl (15.2 ppm) recorded the lowest $\mathrm{NO}_{3}-\mathrm{N}$ concentration for red-leaf lettuce cultivars. 'Ridgeline' a romaine lettuce type, showed the lowest $\mathrm{NO}_{3}-\mathrm{N}$ concentration accumulation (5.2 ppm) within all four categories of lettuce. However, of the top-performing cultivars, there were no statistical differences in $\mathrm{NO}_{3}-\mathrm{N}$ concentrations among the three cultivars Ridgeline (5.2 ppm), Green Towers (11.2 ppm), and Salad Bowl (10.6 ppm) (Table 3 ).

\section{Discussion}

Cultivar trial. Lettuce producers strive to sell high-quality products to ensure good returns on investment. Wholesale lettuce is sold on a weight basis whereas freshmarket lettuce can be sold either on a weight basis or as a set price per individual head. Identifying lettuce cultivars that produce heavier fresh weights is helpful when advising Louisiana producers on cultivars that will make a positive return on investment, as many Louisiana producers sell produce to the direct market (N.F. Jones, personal communication). Because buyers often want one or more types of lettuce, recommendations were made for each of the four categories of lettuce. Of the romaine cultivars produced in this study, 'Ridgeline', is recommended for commercial production in Louisiana, with an average fresh weight of $550.4 \mathrm{~g}$. If weight is the sole factor in selecting a lettuce cultivar to grow, Louisiana producers should grow romaine lettuce when weight dictates price. However, if consumer preference demands other lettuce types, then the second highest yielding lettuce category in the LSU AgCenter study was crisphead lettuce. The butterhead lettuce type ranked third in fresh weight; leaf lettuce types ranked last in fresh weight (Table 2). Among romaine cultivars of lettuce grown in the current study, Green Towers had the greatest fresh weight, similar to the results of Kemble et al. (2012). However, the weight of 'Green Towers' was similar to the fresh weight of 'Ridgeline'. Spalding and Coolong (2008) also found that 'Green Towers' produces one of the greatest fresh weights when trialed in Georgia, similar in weight to all other romaine cultivars included in the study. Maynard (2013) found similar results in Indiana, where 'Green Towers' produced one of the greatest fresh weights among romaine cultivars. Within the crisphead type, 'Raider' had the greatest fresh weight but was no different from the three other crisphead cultivars tested (Table 1). Within butterhead types, 'Harmony' and 'Caliente' had the first (472 g) and second (460.9 g) greatest fresh weights, respectively, out of all the other cultivars tested, but were similar in weight to Adriana (376.9 g), Buttercrunch (377.6 g), and Sylvesta (401.4 g). 'Harmony' and 'Caliente' were not included in the Indiana study, but 'Adriana' and 'Sylvesta' were recommended for further testing (Maynard, 2013). Kemble et al. (2012) conducted leaf lettuce cultivar trials in southern Alabama and found similar results to the LSU AgCenter study. Leaf lettuce cultivars Oakleaf and Salad Bowl produced the greatest fresh weight (250.6 and $229.1 \mathrm{~g}$, respectively). Although 'Oakleaf' 
Table 1. Average fresh weight of individual lettuce heads and germination rates of lettuce cultivars evaluated in the Louisiana State University southern Louisiana 2011-12 trials.

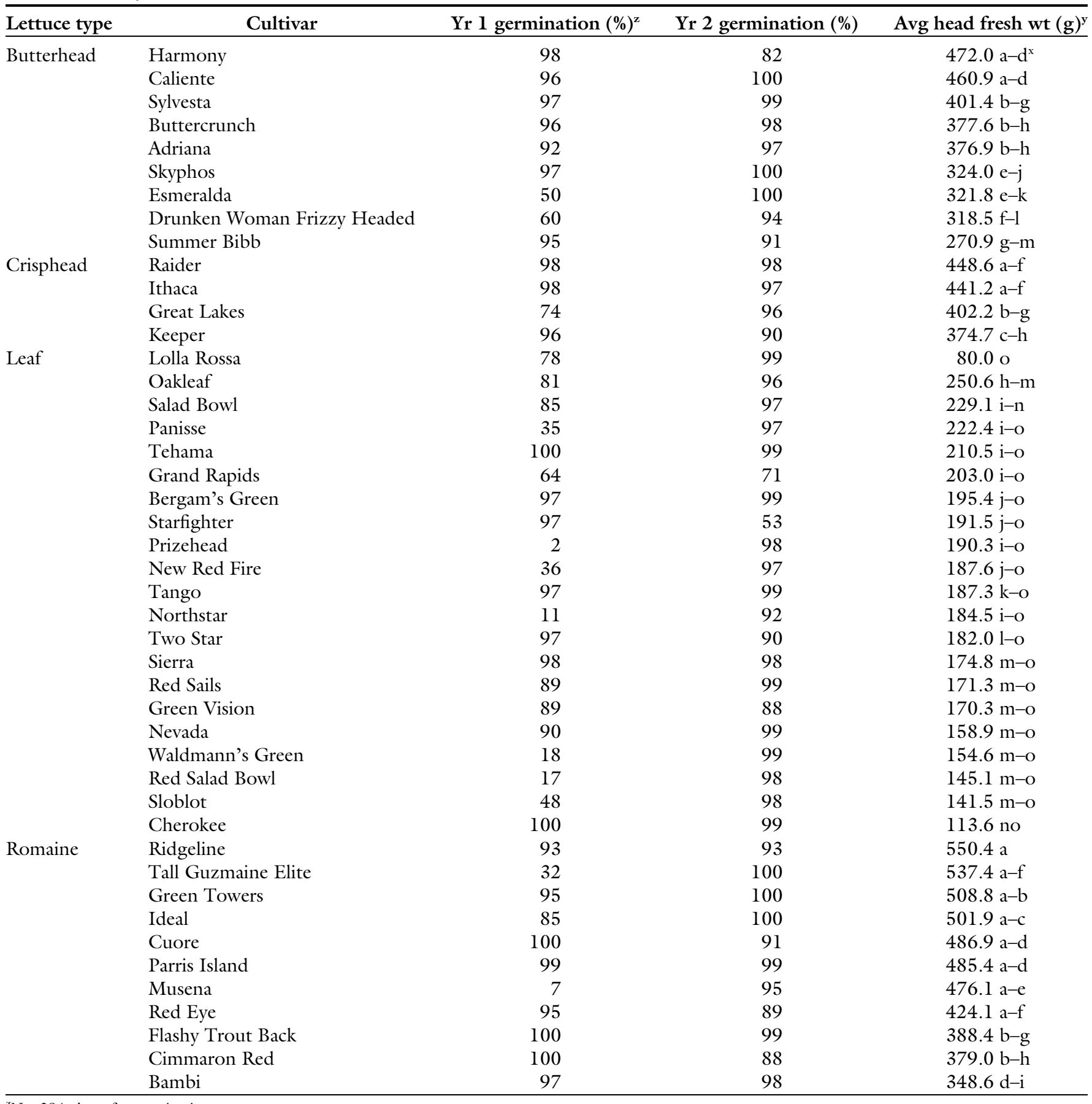

${ }^{\mathrm{z}} \mathrm{N}=294$ plants for germination rates.

${ }^{\mathrm{y}} \mathrm{l} \mathrm{g}=0.0353 \mathrm{oz}$.

${ }^{\mathrm{x}}$ Mean comparison within columns by SAS (version 9.2; SAS Institute, Cary, NC) with Tukey's test at $P \leq 0.05$. Means with the same letter do not differ at the $5 \%$ significance level.

and 'Salad Bowl' were not included in the study by Kemble et al. (2012), 'Bergam's Green', 'Nevada', 'New Red Fire', 'Northstar', and 'Starfighter' were included. 'Starfighter' and 'Northstar' produced the greatest fresh weights in Alabama (Kemble et al., 2012) and were not different from 'Oakleaf' and 'Salad Bowl'
(Table 1) in the LSU AgCenter study. In the Indiana study, 'Panisse' produced some of the greatest fresh weights of the cultivars tested (Maynard, 2013), similar to the fresh weights recorded in the Indiana study and our study (Table 3 ). Although minor differences were found among the three studies, it appears lettuce cultivars are somewhat similar in production capabilities when produced in the southeastern portion of the United States. Louisiana lettuce producers looking for specific cultivars with the greatest average fresh weight within the romaine type should grow Ridgeline and Green Towers. For crisphead type lettuce, Louisiana 
Table 2. Fresh weight and nitrate concentration measured on individual lettuce heads categorized by the four lettuce types evaluated in the Louisiana State University southern Louisiana 2011-12 lettuce cultivar trials.

\begin{tabular}{lcc}
\hline Lettuce type & Avg head fresh wt $(\mathrm{g})^{\mathrm{z}}$ & Nitrate $(\mathbf{p p m})^{\mathrm{y}}$ \\
\hline Romaine & $462.5 \mathrm{a}^{\mathrm{x}}$ & $8.2 \mathrm{~b}$ \\
Crisphead & $416.7 \mathrm{~b}$ & $16.2 \mathrm{a}$ \\
Butterhead & $369.4 \mathrm{c}$ & $17.8 \mathrm{a}$ \\
Leaf & $178.4 \mathrm{~d}$ & $16.9 \mathrm{a}$ \\
\hline
\end{tabular}

${ }^{\mathrm{z}}$ Fresh weight is the fresh weight of individual harvested lettuce heads measured in the field before removal of wrapper leaves; $1 \mathrm{~g}=0.0353 \mathrm{oz}$.

${ }^{\mathrm{y}}$ Using the average percent water of lettuce, $2 \mathrm{~g}$ of dried lettuce tissue is equivalent to $43 \mathrm{~g}$ of fresh-weight lettuce. The calculation is as follows: $2 \mathrm{~g}$ dried $\times[100 /(100-95.4)]=43 \mathrm{~g}$ fresh (Maynard and Hochmuth, 2007); $1 \mathrm{ppm}$ $=1 \mathrm{mg} \cdot \mathrm{kg}^{-1}$.

${ }^{x}$ Mean comparison within columns by SAS (version 9.2; SAS Institute, Cary, NC) with Tukey's test at $P \leq 0.05$ Means with the same letter do not differ at the $5 \%$ significance level.

Table 3. Heaviest fresh-weight lettuce cultivars' nitrate-nitrogen concentration evaluated in the Louisiana State University southern Louisiana 2011-12 lettuce cultivar trials.

\begin{tabular}{llc}
\hline Lettuce type & \multicolumn{1}{c}{ Cultivar } & Nitrate-nitrogen $(\mathbf{p p m})^{\mathbf{z}}$ \\
\hline Butterhead & Caliente & $4.90 \mathrm{ab}^{\mathrm{y}}$ \\
Crisphead & Harmony & $3.16 \mathrm{bc}$ \\
& Raider & $4.0 \mathrm{a}-\mathrm{c}$ \\
Leaf & Ithaca & $3.39 \mathrm{bc}$ \\
& Cherokee & $4.98 \mathrm{ab}$ \\
& New Red Fire & $5.45 \mathrm{a}$ \\
& Red Sails & $3.50 \mathrm{a}-\mathrm{c}$ \\
& Red Salad Bowl & $3.45 \mathrm{a}-\mathrm{c}$ \\
& Salad Bowl & $2.41 \mathrm{~cd}$ \\
Romaine & Tango & $3.32 \mathrm{bc}$ \\
& Two Star & $3.61 \mathrm{a}-\mathrm{c}$ \\
& Ridgeline & $5.18 \mathrm{~d}$ \\
& Green Towers & $2.55 \mathrm{~cd}$ \\
\hline
\end{tabular}

${ }^{\mathrm{z}}$ Using the average percent water of lettuce, $2 \mathrm{~g}$ of dried lettuce tissue is equivalent to $43 \mathrm{~g}$ of fresh-weight lettuce. The calculation is as follows: $2 \mathrm{~g}$ dried $\times[100 /(100-95.4)]=43 \mathrm{~g}$ fresh (Maynard and Hochmuth, 2007); $1 \mathrm{~g}=$ $0.0353 \mathrm{oz}, \mathrm{l} \mathrm{ppm}=1 \mathrm{mg} \cdot \mathrm{kg}^{-1}$.

${ }^{y}$ Mean comparison within columns by SAS (version 9.2; SAS Institute, Cary, NC) with Tukey's test at $P \leq 0.05$. Means with the same letter do not differ at the $5 \%$ significance level.

producers should grow 'Raider' and 'Ithaca'. For butterhead type lettuce, Louisiana producers should grow 'Caliente' and 'Harmony', whereas 'Oakleaf' and 'Salad Bowl' should be grown if leaf lettuce is desired. 'Harmony' was not only a heavy yielding lettuce cultivar, but also it was a top choice for consumers in year 2 .

$\mathrm{NO}_{3}{ }^{-}$sTUDY. Cultivars that yielded the greatest fresh weights in the 2011-12 cultivar trials were analyzed for $\mathrm{NO}_{3}-\mathrm{N}$ concentration (Table 3$) . \mathrm{NO}_{3}-\mathrm{N}$ concentrations were compared using the RfD (the Environmental Protection Agency's maximum acceptable oral dose of a toxic substance) for $\mathrm{NO}_{3}^{-}$: “The $\mathrm{RfD}$ is based on the assumption that thresholds exist for certain toxic effects such as cellular necrosis. In general, the RfD is an estimate (with uncertainty spanning perhaps an order of magnitude) of a daily exposure to the human population (including sensitive subgroups) that is likely to be without an appreciable risk of deleterious effects during a lifetime" (EPA, 1991). The Centers for Disease Control (CDC) calculates average weights of U.S. male and female inhabitants ages 20 to 74 years old as 86.8 and $74.7 \mathrm{~kg}$, respectively (CDC, 2004). Using the EPA's RfD of $1.6 \mathrm{mg} \mathrm{NO}_{3}$ $\mathrm{N}$ per kilogram body weight per day, the $\mathrm{RfD}$ of $\mathrm{NO}_{3}{ }^{-}$for males is 138.88 $\mathrm{mg} \cdot \mathrm{d}^{-1} \mathrm{NO}_{3}-\mathrm{N}$. The RfD of $\mathrm{NO}_{3}{ }^{-}$for females is $119.52 \mathrm{mg} \cdot \mathrm{d}^{-1} \mathrm{NO}_{3}-\mathrm{N}$. The leaf lettuce cultivar New Red Fire had the greatest $\mathrm{NO}_{3}-\mathrm{N}$ concentration (mean, $5.45 \mathrm{mg} \mathrm{NO}-\mathrm{N}$ ), accounting for $3.92 \%$ of the RfD for men and $4.56 \%$ of the RfD for women (Table 3). The lowest concentration of $\mathrm{NO}_{3}^{-}$was found in the lettuce cultivar Ridgeline, a romaine lettuce type. Its $\mathrm{NO}_{3}-\mathrm{N}$ concentration accounted for $1.18 \%$ of the RfD for men and $0.99 \%$ of the RfD for women (Table 3). For the segment of the U.S. population concerned with $\mathrm{NO}_{3}{ }^{-}$levels in food, including vegetables, $\mathrm{NO}_{3}{ }^{-}$levels recorded in this study are an important reference for lettuce consumption. Red-leaf cultivars generally had greater $\mathrm{NO}_{3}{ }^{-}$concentrations than green-leaf cultivars when grown with the recommended fertilization schedule. However, Brkić et al. (2017) found that, although vegetable crops-specifically, arugula (Eruca sativa), lettuce, chard (Beta vulgaris), spinach (Spinacia oleracea), kale (Brassica oleracea), and cabbage (Brassica oleracea)contain a significant amount of nitrates, they are still within acceptable amounts for most adult vegetarians. However, adults with significant health concerns may want to limit consumption of high nitrates in vegetables until conclusive research is completed in this area. According to Ohio's Environmental Protection Agency Division of Drinking and Ground Waters, healthy adults and older children can consume more nitrate than infants, because infants do not have fully developed digestive systems (Ohio Environmental Protection Agency, 2014). It is important to note that baby foods are traditionally made from sweetpotatoes (Ipomoea batatas), squash (Cucurbita maxima), peas (Pisum sativum), carrots (Daucus carota), corn (Zea mays), and other vegetablesnot typically lettuce. Therefore, we did not research recommended rates of nitrates for infants. However, it is prudent for nursing women to consider their total nitrate consumption when breastfeeding.

\section{Literature cited}

Afton, W. 2018. Evaluation of growth characteristics, yield, marketability and nitrate levels of lettuce (Lactuca sativa) cultivars produced in south Louisiana. MS Thesis, Louisiana State Univ., Baton Rouge. 6 June 2020. <https:// digitalcommons.lsu.edu/gradschool_ theses $/ 4382 />$.

Brkić, D., J. Bošnir, M. Bevardi, A. Gross Bošković, S. Miloš, D. Lasić, A. Krivohlavek, A. Racz, A. Mojsović Ćuić, and N. Uršulin Trstenjak. 2017. Nitrate in leafy green vegetables and estimated intake. Afr. J. Tradit. Complement. Altern. Med. 14(3):31-41. 
Boudreaux, J. 2009. Louisiana commercial vegetable production recommendations. Louisiana Coop. Ext. Serv. Publ. 2433.

Centers for Disease Control. 2004. Americans slightly taller, much heavier than 40 years ago. 18 Aug. 2020. <https://www.cdc.gov/media / pressrel/r041027.htm>.

Hill, M.J. 1996. Nitrates and nitrites in food and water. Woodhead Publishing, Sawston/Cambridge, UK.

Kemble, J., K. Jennings, and J. Walgenbach. 2019. Southeastern vegetable crop handbook. Meister Media Worldwide, Willoughby, $\mathrm{OH}$.

Kemble, J., E. Vinson, R. Akridge, and J. Burkett. 2012. Lettuce trials conducted in south and central Alabama, p. 11-12. In: Fall 2011 commercial fruit and vegetable variety trials. Auburn University, Auburn, AL.

Maynard, E. 2013. Lettuce cultivar observation trial 2013, p. 41-50. In: Midwest vegetable trial report for 2013. Purdue University, West Lafayette, IN.

Maynard, D. and G. Hochmuth. 2007. Knott's handbook for vegetable growers. 5 th ed. Wiley, Hoboken, NJ.
Ohio Environmental Protection Agency Division of Drinking and Ground Waters. 2014. Nitrate in public drinking water. 6 May 2020. <https://www.epa.state.oh. us / Portals /28/documents / pws/ Nitrate_in_Public_Drinking_Water.pdf $>$.

Sen Nag, O. 2017. World leaders in lettuce production. 27 May 2020. <https:// www.worldatlas.com/articles/worldleaders-in-lettuce-production.html>.

Spalding, D. and T. Coolong. 2008. Romaine lettuce cultivar trial, p. 28-29. In: E. Maynard (ed.). Midwest vegetable trial report for 2008. Purdue University, West Lafayette, IN.

Swiader, J. and G. Ware. 2002. Producing vegetable crops. 5th ed. Pearson, London, UK.

U.S. Department of Agriculture. 2011a. U.S. lettuce: Per capita use, 1960-2010. 27 May 2020. <https://usda.mannlib.cornell. edu/MannUsda/viewDocumentInfo.do? documentID $=1576>$.

U.S. Department of Agriculture. 2011b. U.S. romaine lettuce: Acreage, yield, production, and value, 1992-2009. 27 May 2020. <https://usda.mannlib.cornell.
edu/MannUsda/viewDocumentInfo.do? documentID $=1576>$.

U.S. Department of Agriculture. 2011c. U.S. leaf lettuce: Acreage, yield, production, and value, 1992-2009. 27 May 2020. <https://usda.mannlib.cornell. edu/MannUsda/viewDocumentInfo. do?documentID $=1576>$.

U.S. Department of Agriculture. 2011d. U.S. head lettuce: Acreage, yield, production, and value, 1950-2009. 27 May 2020. <https://usda.mannlib.cornell. edu/MannUsda/viewDocumentInfo. do?documentID $=1576>$.

U.S. Environmental Protection Agency. 1991. Nitrate; CASRN 14797-55-8. 10 May 2020. <https://cfpub.epa.gov/ ncea/iris/iris_documents/documents/ subst/0076_summary.pdf $>$.

U.S. Environmental Protection Agency. 1993. Method 351.2, revision 2.0: Determination of total kjeldahl nitrogen by semi-automated colorimetry. 1 July 2017. $<$ ht p : / / www.epa.gov/sites / production/files/2015-08/documents/ method_351-2_1993.pdf>.

Ward, M., R. Jones, J. Brender, T. de Kok, P. Weyer, B. Nolan, C. Villanueva, and S. van Breda. 2018. Drinking water nitrate and human health: An updated review. Intl. J. Environ. Res. Health 15:1557. 